Review article

\title{
Introduction to bigorexia
}

\author{
Šárka Tovt, Alena Kajanová * \\ University of South Bohemia in České Budějovice, Institute of Social and Special-paedagogical Sciences, České Budějovice, Czech Republic
}

\section{Abstract}

Bigorexia was first mentioned in the early 20th century in the USA. It is an unanchored disease with elements of obsessive-compulsive disorder. It is characterized by an obsession with the appearance of one's body, fear of not having enough muscles, and the urgent need for excessive physical exercise. The disorder can cause other serious illnesses and is also often associated with dependence on anabolic steroids or other addictive substances.

The aim of this article is to provide basic information about the problem of bigorexia, including the diagnosis and treatment. It also deals with the possible health and social risks in people suffering from bigorexia.

This article presents a set of results of the existing literature in the field of muscle dysmorphia from Web of Science, PubMed, Scopus and other related scientific databases. The studied professional articles were not limited by the date of publication, as the original works provide insight into the initial investigation of bigorexia and the mapping of this disease. The search was performed using keywords related to the issue. The scientific articles were supplemented by diagnostic and statistical manuals and monographs.

The research revealed that the issue of bigorexia is mainly dealt with in foreign countries. In the Czech Republic, relevant data regarding this disease is currently lacking. The existing foreign research has mainly been applied to the male population. The data in the female population is mostly missing.
\end{abstract}

Keywords: Adonis complex; Bigorexia; Body dysmorphic disorder; Muscle dysmorphia

\section{Introduction}

The concept of bigorexia is not well known in the Czech environment, as evidenced by the absence of relevant scientific studies. We used the method of content analysis of documents. Relevant sources were searched via the scientific databases PubMed, Scopus and Web of Science, without time limit. The search was performed using the keywords "bigorexia", "muscle dysmorphia", "Adonis complex", "body dysmorphic disorder", and the Boole operators "and" and "or". We also used bibliographies for specific selected studies to find additional documents. In the first phase of the search, we found 1,070 studies. In the next phase of the analysis, all duplicates and irrelevant studies or studies without a full-text version were removed. The resulting number of used studies was 39. These studies specifically focused on the issue of muscle dysmorphia; 36 research articles, of which 23 are case studies, 4 cross-sectional, 9 review and 1 excluded study. The studies were conducted in various countries such as the USA, South Africa, Italy and Australia. The articles were supplemented by 2 statistical and diagnostic manuals and 1 book. In the Czech Republic, only a few diploma or bachelor's theses have dealt with this topic. These documents were excluded from the sources in order to gather the best possible information available. The collection and analysis of results were carried out between October and November 2020. The goal of this article is to provide current and comprehensive knowledge about muscle dysmorphia.

\section{Bigorexia as a concept}

Bigorexia, also known as the Adonis complex, muscular dysmorphia, or reverse anorexia, is a disorder predominantly present in men. Individuals experience feelings of dissatisfaction with their body size and general musculature. The everyday life of bigorexics revolves around lifting heavy weights and dieting. The consequence of this behaviour is extreme anxiety regarding other people's perceptions of their bodies, impaired social functioning, and abuse of anabolic steroids/other substances (Pope et al., 1997). People suffering from bigorexia are exposed to significant health or social risks due to strict adherence to dietary regimens, excessive exercising, and substance abuse. Some researchers believe that the disorder is one of the forms of dysmorphic disease (Kanayama and Pope, 2011), while others see bigorexia as a type of eating disorder (Mosley, 2009; Murray et al., 2010; 2016; Raevuori et al., 2008). Devrim et al. (2018) found that there is a positive relationship between eating disorders and dissatisfaction with one's body, dysmorphic disorder, and bigorexia.

\footnotetext{
* Corresponding author: Alena Kajanová, University of South Bohemia in České Budějovice, Institute of Social and Specialpaedagogical Sciences, Jírovcova 1347/24, 37004 České Budějovice, Czech Republic; e-mail: kajanova@zsf.jcu.cz http://doi.org/10.32725/kont.2021.014 


\section{Prevalence and diagnostics}

One of the first studies in the field of bigorexia began with a survey of the use of anabolics in 108 men who were involved in heavy weightlifting. Ten percent of the total number of men who participated in this research described themselves as physically small and weak, despite the fact that they were in fact perceived as large and over muscled. Researchers have described this phenomenon as reverse anorexia.

Research conducted in the Western Cape showed that $53.6 \%$ of amateur fitness competitors (both men and women) showed signs of bigorexia (Hitzeroth et al., 2001). Another study on bodybuilders in Italy showed a prevalence of bigorexia in $25.9 \%$ of 170 people (Fabris et al., 2018). Devrim et al. (2018) described the incidence of bigorexia in $58 \%$ of 120 bodybuilders. Bigorexia shows very similar features to anorexia, but with opposite symptoms (Pope et al., 1993). Both disorders involve an impaired perception of one's body, both probably reflect cultural expectations - anorexia is primarily a women's disorder, which is very often associated with increasing pressure from the environment to be slim, but bigorexia, on the contrary, deals with increasing pressure from the environment to be sufficiently muscular and large (Pope et al., 1997). One of the diagnostic factors is the fear of impaired body perception and negative evaluation regarding weight or body shape. In their longitudinal study of 4,030 adolescents (both women and men), Trompeter et al. (2019) found that the fear of negative body evaluation was associated with a higher probability of developing bigorexia. At the same time, Pope et al. (1993) hypothesized that bodybuilders may be at much greater risk of dysmorphic disorder as a whole, and that sociocultural factors may influence whether they develop anorexia or bigorexia.

There is very little research on the issue of bigorexia in women (Gruber and Pope, 1999). One example is the research of Zeeck et al. (2018), which uses the Muscle Dysmorphia Disorder Inventory tool. In their research, they focused on assessing the relationship between bigorexia, one's relationship to their body, and their dependence on exercise. The study involved 394 people, of which 53\% were women. The results showed that men show a much greater desire to be muscular than women. Similar results were also shown by the research of Diehl et al. (2016), who stated that despite the greater participation of women than men in the study, men had significantly more symptoms of bigorexia than women. Women, on the other hand, showed higher intolerance scores. Men and women had different symptoms of bigorexia, although both groups showed similar overall bigorexia scores. It is also necessary for them to consider the concept of their own body (as men and women), as the level of satisfaction with a given body area differs. For example, men are more dissatisfied with their muscles, while women are more likely to be dissatisfied with their chest area (Perugi et al., 1997; Phillips and Diaz, 1997; Phillips et al., 2006).

First of all, it is necessary to define bigorexia as a specific type of illness. Foreign countries debate as to whether bigorexia is a subcategory of dysmorphic disorder (Pope and Katz, 1994) or only part of the disorder as a whole. On the other hand, the behaviour of bigorexic people is closer to obsessive-compulsive disorder (Maida and Armstrong, 2005), which is based on a chronic obsession with certain actions (e.g., avoiding social gatherings to maintain exercise schedules, increasing exercise time due to the negative perception of their body, etc.), which is not an indication of dysmorphic disorder (Chung, 2001). We should say that bigorexia has many important clinically significant differences to other forms of dysmorphic disorder, but it is important to be identified for targeted treatment. We should not forget that muscle dysmorphia may also be close to eating disorders (Hitzeroth et al., 2001). For example, the research of Gorrassi et al. (2019) identified the risk of eating disorders in 918 university students, of whom 5\% were diagnosed with bigorexia. These individuals had a statistically significantly higher risk of eating disorder prevalence. The research of Behar and Molinari (2010) also found a higher score in the weight-loss test in the group of weightlifters who had been diagnosed with muscle dysmorphia compared with weightlifters without weight-diagnosed muscle dysmorphia. The research of Duran et al. (2020), which included 430 male students, found that students' tendency to orthorexia increases with an increasing tendency to bigorexia.

In the International Classification of Diseases we do not find muscle dysmorphia as such. We can only find a dysmorphic disorder that falls into the category of hypochondriac disorders (WHO, 1992). On the other hand, the Diagnostic and Statistical Manual of Mental Disorders mentions muscular dysmorphia as a type of obsessive-compulsive disorder (APA, 2013). Pope et al. (1997) propose the following basic diagnostic criteria: a person is obsessed with a non-existent defect in appearance, judges their own body, which causes impairments in the functioning in social, work, or other important areas of life, and is obsessed with diet and exercise.

One of the questionnaires that can be used to measure the degree of bigorexia is the Drive for Muscularity Scale. During the development of this questionnaire, a group of people (both men and women) who dealt with strength training were addressed. They were asked, among other things, how they felt if they missed their training. Based on their answers, a 15-item Drive for Muscularity Scale questionnaire was created. The questionnaire measures attitudes and behaviours that reflect the degree of interest in their own musculature. Each item is rated on a six-point scale from never to always (McReary and Sasse, 2000).

Another questionnaire is the Adonis Complex Questionnaire, which was created to assess body image. It contains a relatively wide range of topics that deal with activities in everyday life and is intended for men only, but does not provide detailed information on the severity of symptoms. The questionnaire consists of 13 questions, and the higher the value, the greater the tendency to bigorexia (Pope et al., 2000a).

On the other hand, Muscle Dysmorphia Disorder Inventory measures the symptoms of bigorexia. It is a 13-item questionnaire with three subscales: effort for size, intolerance of physical appearance, and functional impairment (Hildebrandt et al., 2004). Another questionnaire that can measure bigorexia is the Muscle Dysmorphia Inventory. This is a 34-item questionnaire that reflects 4 basic diagnostic criteria according to Pope et al. (1997).

\section{Treatment}

There is currently no comprehensive framework for the treatment of bigorexia. However, the findings can be applied in the treatment of the obsessive-compulsive disorder, dysmorphic disorder, and eating disorders. That being said, individuals with muscular dysmorphia rarely seek treatment, and if so, the requirements relate mainly to symptoms of depression due to the poor perception of their body or substance abuse (Olivardia, 2001). One option is cognitive-behavioural therapy. Cognitive strategies involve identifying distorted thinking and looking at one's body, e.g., thoughts like "if my body is not perfect and muscular enough, it is disgusting." People suffering from bigorexia should learn to observe these ideas and 
suppress them. Behavioural strategies draw their foundations from eating disorders/dysmorphic disorders and focus on controlling impulsive behaviour, i.e., reducing repetitive behaviour (e.g., regularly looking into the mirror, but also overeating) or social exposure (people suffering from bigorexia often find it inconceivable to take off the upper part of their clothing in public or to take part in a social event at the expense of regular training). In their study on the benefit of cognitive-behavioural therapy in dysmorphic disorders, Willhelm et al. (2014) reported more than a $53 \%$ reduction in symptoms in those who completed the entire process of 24 weeks of therapy. Serotonin reuptake inhibitors may be used in pharmacotherapy, which may be effective in the obsession and urge that is typical for this disorder (Hollander et al., 1999).

\section{Health risks}

One of the health risks of trying to be as muscular as possible is the use of anabolic steroids (Pope et al., 1993; 2005). By using these substances, people with bigorexia are at a much higher risk of coronary heart disease, kidney and liver damage, including immune system damage (Perry et al., 1992). Steroids are injected into large muscle groups (buttocks, thighs, shoulders), however, not intravenously. The risk of needle sharing among steroid users and the associated transmission of other diseases such as HIV and hepatitis may also be associated with the application of steroids (Midgley et al., 2010). Users usually take steroids in cycles of 6 to 12 weeks, followed by the same time period without taking steroids and then resuming the course of treatment. At the beginning of the cycle, small doses are taken with a gradual increase, but continuous use is not unusual. It is used to increase muscle volume and avoid withdrawal symptoms. The side effects of these substances are also associated with aggression, paranoia, anxiety or depression, a reduction in sexual libido, erectile dysfunction (especially at the end of the steroid cycle), or severe acne (O'Sullivan et al., 2000).

One of the other health risks is exercising despite severe pain or acute injury. One of the bigorexics, for example, stated that even though he had a hernia, he continued with intense to extreme squatting with an almost 184-kilo barbell on his shoulders. He also described the pain as really unbearable, but when it was bearable, he continued to lift the weight again, despite the injury. People who suffer from bigorexia can inflict very serious orthopaedic injuries on themselves with extreme exercising (Pope et al., 2000b). People with muscular dysmorphia can break their bones or damage their ligaments through excessive exercise due to the excessive strain on the musculoskeletal system and the consequent fear that their muscularity will decrease (Olivardia, 2001).

It is also important to mention the diet aspect of bigorexics. They follow a very strict and often unbalanced nutritional plan with high protein content, up to $5 \mathrm{~g}$ for every $1 \mathrm{~kg}$ of body weight, which can ultimately cause kidney damage (Friedman, 2004). Pope et al. (2005) pointed out that bigorexics statistically significantly show signs of prevalent substance use, suicide risk, and a significantly higher level of psychopathology in relation to the quality of life. The relationship between bigorexia and psychopathology has been studied by Longobardi et al. (2017). The study included 145 Italian male bodybuilders. These individuals showed a much higher risk of psychopathology compared to other male bodybuilders without signs of bigorexia.

\section{Social risks}

People with bigorexia often give up social activities to achieve their goals in exercise. Other characteristic behaviours include impaired functioning in other areas of social life. Most bigorexics purposefully avoid places where they might have to show their figure (swimming pools, locker rooms, beaches). These situations are very unpleasant for them and cause strong anxiety (Olivardia et al., 2000; Pope et al., 1997). The most common answer in the research of Olivardia (2001) on the symptoms of muscle dysmorphia, was that these people had given up most social contacts (friends and family) at the expense of exercise - and this included truancy. The vast majority of the respondents described how, in summer, they preferred to be covered up (it is not unusual for them to wear warm sweaters or jackets regardless of the outdoor temperature) than be seen in short-sleeved clothing. They also wore layers of clothes to look more muscular (Olivardia, 2001). In his research, Olivardia (2001) mentions a man who missed the birth of his child because he feared that if he missed training, his musculature would shrink. Another man had to be fired because he was going to practice during his hour's lunch break with one training usually taking him three to four hours. We can say that the fear of losing the gained muscle mass is much greater than the possible disruption of personal relationships. In another study, several people stated that they preferred to live alone so that the presence of another person in the household did not jeopardize their diet and exercise plan (Pope et al., 1997). People with bigorexia often follow a diet high in protein, low in fat, and a specific total calorie intake per day. If for some reason they deviate from this diet, anxiety arrives with the urge to immediately compensate, e.g., further training. For this reason, they may also avoid dieting with another person (Pope et al., 1997).

Avoiding social contact significantly alleviates the anxiety concerns of people with bigorexia, so they are at risk of social exclusion.

\section{Discussion}

There is currently no study in the Czech Republic that maps the prevalence of bigorexia in bodybuilders or fitness professionals. The question is: what is the cause of this lack of research? In response, we can talk about the lack of a standardized tool for the Czech population that could be used, and also the general awareness of this disease. It is also necessary to think about the target group in terms of gender. Most research is conducted on men (Gruber and Pope, 1999), but a few foreign studies show that bigorexia can also be found in women, but with different symptoms (Perugi et al., 1997; Phillips and Diaz, 1997; Phillips et al., 2006). Symptoms in women and men, i.e., their diversity should be the subject of further research.

Another area of discussion is the anchoring of bigorexia as a specific disorder or disease. Bigorexia is discussed in the fifth edition of the Diagnostic and Statistical Manual of Mental Disorders as one of the diagnostic criteria for bodily dysmorphic disorders. However, the question is whether it belongs to this category. For example, Chung (2001) states that bigorexia involves a strict diet similar to anorexia and elements of obsessive-compulsive disorder, but this is not a rule for the classification of a dysmorphic disorder. As for eating disorders, 
in bigorexia, this is considered one of the symptoms of the disorder, not the disorder itself, although some scientists are inclined to believe that bigorexia should be considered one of the types of eating disorders.

\section{Conclusions}

This review article summarizes the results of studies that point out the necessity of identifying bigorexia as a specific type of disease, i.e., either as an eating disorder or as a dysmorphic disorder, including the relationship to each other or other psychiatric disorders. The research is mostly conducted on the male population, but relevant data also need to be obtained for the female population. Socio-cultural perception of the image of an ideal body is undergoing a transformation - see the current possibilities of professional/amateur bodybuilding in women and their involvement in competitions that were not as common as before. Early diagnostics with appropriate tools, a sufficient knowledge base of the issue, and the implementation of adequate treatment or support measures is key. Given that strength training is an increasingly popular activity regarding a healthy lifestyle, it is necessary to educate the general public (and also psychologists, dietitians, professional coaches) about the risky types of behaviour in sports - to which bigorexia undoubtedly belongs. Future research should focus not only on the mentioned prevalence in both sexes but also on the possible risks, including a focus on different age groups - such as adolescents.

\section{Conflict of interests}

The authors have no conflict of interests to declare.

\section{Úvod do problematiky bigorexie}

\section{Souhrn}

Bigorexie byla poprvé zmíněna na počátku 20. století ve Spojených státech amerických. Jedná se o zatím neukotvenou nemoc s prvky obsedantně kompulzivní poruchy, která se vyznačuje posedlostí vzhledem svého těla, obavou nad dostatkem svalů a nutkající potřebou nadměrného fyzického cvičení. Porucha může být příčinou dalších závažných onemocnění a je také často spojená se závislostí na anabolických steroidech či jiných návykových látkách.

Cílem předkládaného článku je poskytnutí základních informací o problému bigorexie, včetně diagnostiky, léčby tohoto onemocnění a zabývá se také možnými zdravotními/sociálními riziky u osob trpících bigorexií.

Předkládaný text je souborem výsledků stávající literatury v oblasti svalové dysmorfie, čerpané z vědeckých databází Web of Science, PubMed, Scopus a dalších př́ibuzných databází. Prohledané odborné články nebyly limitovány datem vydání, nebot' původní práce poskytují vhled do prvopočátečního zkoumání bigorexie a zmapování tohoto onemocnění. Vyhledávání proběhlo pomocí klíčových slov vázajících se $\mathrm{k}$ dané problematice, vědecké články byly doplněny diagnostickými a statistickými manuály a monografií.

Výzkumem bylo zjištěno, že problematikou bigorexie se převážně zabývají zahraniční země, v České republice prozatím chybí relevantní data týkající se tohoto onemocnění. Stávající výzkumy v zahraničí jsou aplikované zejména na mužskou populaci, chybějící data jsou převážně u ženské populace.

Klíčová slova: Adonisův komplex; bigorexie; dysmorfofobická porucha; svalová dysmorfie

\section{References}

1. American Psychiatric Association - APA (2013). Diagnostic and statistical manual of mental disorders: DSM-5. Arlington, VA, American Psychiatric Association.

2. Behar R, Molinari D (2010). Muscle dysmorphia, body image and eating behaviors in two male populations. Rev Med Chile 138(11): 1386-1394. DOI: 10.4067/S003498872010001200007.

3. Chung B (2001). Muscle dysmorphia: a critical review of the proposed criteria. Perspect Biol Med 44(4): 565-574. DOI: $10.1353 / \mathrm{pbm} .2001 .0062$.

4. Devrim A, Bilgic P, Hongu N (2018). Is There Any Relationship Between Body Image Perception, Eating Disorders, and Muscle Dysmorphic Disorders in Male Bodybuilders? Am J Mens Health 12(5): 1746-1758. DOI: 10.1177/1557988318786868.

5. Diehl BJ, Baghurts T, Durreger C (2016). Biopsychosocial factors in drives for muscularity and muscle dysmorphia among personal trainers. Cogent Psychology 3(1). DOI: 10.1080/23311908.2016.1243194.

6. Duran S, Çiçekoğlu P, Kaya E (2020). Relationship between orthorexia nervosa, muscle dysmorphic disorder (bigorexia), and self-confidence levels in male students. Perspectives in Psychiatric Care 56(4): 878-884. DOI: 10.1111/ppc.12505.

7. Fabris MA, Longobardi C, Prino LE, Settanni M (2018). Attachment style and risk of muscle dysmorphia in a sample of male bodybuilders. Psychology of Men \& Masculinity 19(2): 273-281. DOI: 10.1037/men0000096.

8. Friedman AN (2004). High protein diets: Potential effects on the kidney in renal health and disease. Am J Kidney Dis 44(6): 950-962. DOI: 10.1053/j.ajkd.2004.08.020.

9. Gorrassi ISR, Bonetta S, Roppolo M, Daga GA, Bo S, Tagliabule A, et al. (2019). Traits of orthorexia nervosa and muscle dysmorphia in Italian university students: A multicentre study. Eat Weight Disord 25(5): 1413-1423. DOI: 10.1007/ s40519-019-00779-5.

10. Gruber AJ, Pope HG, Jr. (1999). Compulsive weight lifting and anabolic drug abuse among women rape victims. Compr Psychiatry 40(4): 273-277. DOI: 10.1016/s0010440x(99)90127-x.

11. Hildebrandt T, Langenbucher J, Schlundt DG (2004). Muscularity concerns among men: Development of attitudinal and perceptual measures. Body Image 1(2): 169-181. DOI: 10.1016/j.bodyim.2004.01.001.

12. Hitzeroth V, Wessels CH, Zungu-Dirwayi N, Oosthuizen P, Stein DJ (2001). Muscle dysmorphia: A South African sample. Psychiatry and Clinical Neurosciences 55(5): 521-523. DOI: 10.1046/j.1440-1819.2001.00899.x.

13. Hollander E, Allen A, Kwon J, Aronowitz B, Schmeidler J, Wong C, Simeon D (1999). Clomipramine vs Desipramine Crossover Trial in Body Dysmorphic Disorder: Selective Efficacy of a Serotonin Reuptake Inhibitor in Imagined Ugliness. Arch Gen Psychiatry 56(11): 1033-1039. DOI: 10.1001/ archpsyc.56.11.1033. 
14. Kanayama G, Pope HG, Jr. (2011). Gods, men and muscle dysmorphia. Harv Rev Psychiatr 19(2): 95-98. DOI: 10.3109/ 10673229.2011.565250.

15. Longobardi C, Prino LE, Fabris MA, Settanni M (2017). Muscle dysmorphia and psychopathology: Findings from an Italian sample of male bodybuilders. Psychiatry Res 256: 231-236. DOI: 10.1016/j.psychres.2017.06.065.

16. Maida D, Armstrong SL (2005). The classification of Muscle Dysmorphia. Int J Mens Health 4(1): 73-91. DOI: 10.3149/ jmh.0401.73.

17. McReary DR, Sasse DK (2000). An Exploration of the Drive for Muscularity in Adolescent Boys and Girls. J Am Coll Health 48(6): 297-304. DOI: 10.1080/07448480009596271.

18. Midgley SJ, Heather N, Best D, Henderson D, McCarthy S, Davies JB (2010). Risk behaviours for HIV and hepatitis infection among anabolic-androgenic steroid users. AIDS Care 12(2): 163-170. DOI: 10.1080/09540120050001832.

19. Mosley PE (2009). Bigorexia: Bodybuilding and muscle dysmorphia. Eur Eat Disord Rev 17(3): 191-198. DOI: 10.1002/ erv.897.

20. Murray SB, Griffiths S, Mond JM (2016). Evolving eating disorder psychopathology: Conceptualising Muscularityoriented disorder eating. Br J Psychiatry 208(5): 414-415. DOI: 10.1192/bjp. bp.115.168427.

21. Murray SB, Rieger E, Touyz SW, De la Garza García Lic Y (2010). Muscle dysmorphia and the DSM-V conundrum: Where does it belong? A review paper. Int J Eat Disord 43: 483-491. DOI: $10.1002 /$ eat.20828.

22. Olivardia R (2001). Mirror, Mirror on the Wall, Who's the Largest of Them All? The Features and Phenomenology of Muscle Dysmorphia. Harv Rev Psychiatry 9(5): 254-259. DOI: 10.1080/hrp.9.5.254.259.

23. Olivardia R, Pope HG, Jr., Hudson JI (2000). Muscle Dysmorphia in Male Weightlifters: A Case-Control Study. Am J Psychiatry 157(8): 1291-1296. DOI: 10.1176/appi. ajp.157.8.1291.

24. O’Sullivan, AJ, Kennedy MC, Casey JH, Day RO, Corrigan B, Wodak AD (2000). Anabolic-androgenic steroids: medical assessment of present, past and potential users. Med J Aust 173(6): 323-327. DOI: 10.5694/j.1326-5377.2000.tb125667.x.

25. Perry HM, Wright D, Littlepage BN (1992). Dying to be big: a review of anabolic steroid use. Br J Sports Med 26(4): 259-261. DOI: 10.1136/bjsm.26.4.259.

26. Perugi G, Akiskal HS, Giannotti D, Frare F, Di Vaio S, Cassano GB (1997). Gender-related differences in body dysmorphic disorder (dysmorphophobia). J Nerv Ment Dis 185(9): 578-582. DOI: 10.1097/00005053-199709000-00007.

27. Phillips KA, Diaz SF (1997). Gender differences in body dysmorphic disorder. J Nerv Ment Dis 185(9): 570-577. DOI: 10.1097/00005053-199709000-00006.
28. Phillips KA, Menard W, Fay C (2006). Gender similarities and differences in 200 individuals with body dysmorphic disorder. Compr Psychiatry 47(2): 77-87. DOI: 10.1016/j. comppsych.2005.07.002.

29. Pope HG, Jr., Katz DL (1994). Psychiatric and Medical Effects of Anabolic-Androgenic Steroid Use: A Controlled Study of 160 Athletes. Arch Gen Psychiatry 51(5): 375-382. DOI: 10.1001/ archpsyc.1994.03950050035004.

30. Pope HG, Jr., Gruber AJ, Choi P, Olivardia R, Phillips KA (1997). Muscle dysmorphia. An underrecognized form of body dysmorphic disorder. Psychosomatics 38(6): 548-557. DOI: 10.1016/S0033-3182(97)71400-2.

31. Pope HG, Jr., Gruber AJ, Mangweth B, Bureau B, deCol C, Jouvent R, Hudson JI (2000a). Body image perception among men in three countries. Am J Psychiatry 157(8): 1297-1301. DOI: 10.1176/appi.ajp.157.8.1297.

32. Pope HG, Jr., Katz DL, Hudson JI (1993). Anorexia nervosa and "reverse anorexia" among 108 male bodybuilders. Compr Psychiatry 34(6): 406-409. DOI: 10.1016/0010-440X(93)90066-D.

33. Pope HG, Jr., Phillips KA, Olivardia R (2000b). The Adonis Complex: The Secret Crisis of Male Body Obsession. New York: The Free Press.

34. Pope CG, Pope HG, Menraud W, Fay C, Olivardia R, Phillips KA (2005). Clinical Features of muscle dysmorphia among males with body dysmorphic disorder. Body Image 2(4): 395-400. DOI: 10.1016/j.bodyim.2005.09.001.

35. Raevuori A, Keski-Rahkonen A, Hoek HW, Sihvola E, Rissanen A, Kaprio J (2008). Lifetime anorexia nervosa in young men in the community: Five cases and their co-twins. Int J Eat Disord 41(5): 458-463. DOI: 10.1002/eat. 20525.

36. Trompeter N, Bussey K, Hay P, Griffiths S, Murray SB, Mond J, et al. (2019). Fear of negative evaluation among eating disorders: Examing the association with wight/shape concerns in adolescence. Int J Eat Disord 52(3): 261-269. DOI: 10.1002/ eat. 23018

37. Willhelm S, Phillips KA, Didie E, Buhlmann U, Greenberg JL, Fama JM, et al. (2014). Modular Cognitive-Behavioral Therapy for Body Dysmorphic Disorder: A Randomized Controlled Trial. Behav Ther 45(3): 314-327. DOI: 10.1016/j.beth.2013.12.007.

38. World Health Organization (1992). ICD-10 Classification of Mental and Behavioural Disorders: Diagnostic Criteria for Research. Geneva: World Health Organization.

39. Zeeck A, Welter V, Alatas H, Hildebrandt T, Lahmann C, Hartmann A (2018). Muscle Dysmorphic Disorder Inventory (MDDI): Validation of a German version with a focus on gender. PLoS ONE 13(11): e0207535. DOI: 10.1371/journal. pone.0207535. 